Vesna Sekulic ${ }^{1}$

Milica Pavlovic ${ }^{2}$

University of Nis, Faculty of Economics
ORIGINAL SCIENTIFIC ARTICLE doi:10.5937/ekonomika1804057S Received: October, 09, 2018 Accepted: November, 05, 2018

\title{
CORPORATE SOCIAL RESPONSIBILITY IN RELATIONS WITH SOCIAL COMMUNITY: DETERMINATS, DEVELOPMENT, MANAGEMENT ASPECTS ${ }^{3}$
}

\begin{abstract}
In the contemporary conditions of the pronounces dynamism of competition, clearly articulated demands of the social community and increasingly loud ecological requirements, socially responsible business activities become an indispensable strategy of responsible and ethical management of the company. Depending on how well companies manage socially responsible projects, it depends on the degree of sustainable development and the level of quality of relations with the community. Having this in mind, the paper aims to provide a better and more complete understanding of socially responsible behavior of companies in relations with the social community. Consequently, the significance of social responsibility and the role of social investments for community development are in the focus of the paper. The competencies of corporate social responsibility managers for community development have also been analyzed in order to better understand the new role and responsibility of companies.
\end{abstract}

Key words: corporate social responsibility, community development, social investments

JEL classification: L21,M14,

\section{ДРУШТВЕНА ОДГОВОРНОСТ КОМПАНИЈА У ОДНОСИМА СА ДРУШТВЕНОМ ЗАЈЕДНИЦОМ: КАРАКТЕРИСТИКЕ, РАЗВОЈ, УПРАВЉАЧКИ АСПЕКТИ}

\begin{abstract}
Апстракт
У савременим условима израженог динамизма конкуренције, јасно артикулисаних захтева друштвене заједнице и све гласнијих еколошких захтева, друштвено одговорно пословање постаје неизоставна стратегија одговорног и етичног управљана компанијом. У зависности од тога колико компанија промишљено управља друштвено одговорним пројектима

\footnotetext{
${ }^{1}$ vesna.sekulic@eknfak.ni.ac.rs

${ }^{2}$ milapavlovic@yahoo.com

${ }^{3}$ The paper is part of the Project No. 179066 funded by the Ministry of Education,Science, and Technological Development of the Republic of Serbia
} 
зависи степен юене одрживости и ниво квалитета односа са заједницом. Имајући то у виду, овај рад има за циљь да омогући боље и потпуније разумевање друштвено одговорног понашања компанија у односима са друштвеном заједницом. Сходно томе, значај друштвене одговорности и улога друштвених инвестищија за развој заједнице у фокусу су овог рада. Компетенције менацера корпоративне друштвене одговорности за развој заједнице су такође анализиране у ииљу бољег разумевања нове улоге и одговорности компанија.

Кључне речи: корпоративна друштвена одговорност, развој заједнице, друштвене инвестищије

\section{Introduction}

Including the undertaking of actions that lead to the satisfaction of the company's competitive interests and the interests of the wider community, the socially responsible behavior of modern companies implies, to a significant extent, the creation of good relations with the social community as a significant constituent of their business activities. Therefore, in a wider context, social responsibility is perceived through a broad group of people and groups in a specific geographical area with a common tradition, values, institutions, collective activities and interests (Post, Lawrence, Weber, 2002, p.376).

The social community cooperates with companies and provides them with opportunities for work, so it has certain economic, legal, ethical and philanthropic expectations from them. Consequently, corporate social responsibility can also be considered as a social resource that should contribute to the development of social well-being through the respect of conditions that ensure decent work, sustainable development and environmental protection (at local, regional and global level), through the contribution to government efficiency, as well as through deepening of partnership and dialogue between subjects engaged in the achievement of general social and economic goals. On the other hand, the integration of legal, ethical and ecological principles into a corporate strategy can be a significant source of competitive advantage, so the modern concept of corporate social responsibility implies that companies voluntarily integrate social and environmental problems into their business activities and interactions with stakeholders (Branco Castelo \& Rodrigues Lima, 2007).

Each company independently decides on the way in which it will implement socially responsible business activities. The possible difference occurs due to the effects of certain factors such as the size of companies, the characteristics of the industry within which they operate, the organizational culture of companies, the demands of stakeholders, and so on (Barnett, 2007). Some companies focus on specific areas that are most important to them or areas where they have the greatest impact - for example, human rights or the environment - while others try to integrate corporate social responsibility in all aspects of their business (Campbell, 2007). For the successful implementation of the concept, it is crucial that corporate social responsibility principles are implemented in corporate values and strategic planning, and that both managers and employees be dedicated to them (Tsoutsoura, 2004). 
Kourula i Halme (2008) define three ways of applying socially responsible business activities, each pervades the elements of socially responsible behavior in relations with the social community. The first type of socially responsible business activities of many companies relates to philanthropy, charity actions and donations. Within the second approach, integration of socially responsible business into the entire business is carried out, whereby the companies try to combine responsibility with their basic business activities. As the most represented and at the same time the most important activities can be distinguished investing in research and development, providing high quality products, applying good practice and certain environmental protection measures. The third approach implies that corporate social responsibility is regarded as a source of business innovation, such as introducing new business services models or attempts to solve the problems of socially vulnerable groups.

The main demands of the social community from companies are mostly of economic character. The social community primarily expects economic development, as companies can contribute to the employment of a large number of people, improve health care of the population or activate some underdeveloped part of the community. An economic requirement relates to the payment of taxes, since the revenues collected in this was is extremely important for the financing the state administration at all levels. In recent decades, the more prominent demand of the social community has become ethical behavior of companies, due to the strengthening of the influence of powerful and big corporations on the state policy, thanks to lobbying, political donation of corporations or even corruption, leading to a weakening of the state's ability to protect the social, political and civil rights of the population (Crane\&Matten, 2007, pp. 456-457).

Some authors believe that it is just through corporate social responsibility that institutionalizing and establishing a significant link between market participants, the government and the community (Zadek, 2007). The goal of a partnership that can exist between government, community and companies is not identical in all countries and depends not only on variations in social cohesion, but also on social participation, the situation in political system, historical factors, and the cultural context. (Nga, 2015).

\section{Significance of corporate social responsibility for the social community development}

Corporate social responsibility primarily involves the socially responsible and ethical relationship of the company towards the community in which it earns profit, as well as towards all social actors in the community and in the company (Moir, 2001). Social responsible behavior of companies is reflected in their adoption and realization of discretionary business practice and investments that provide support to the community in order to improve its well-being and environmental protection. Kotler\&Lee (2005) under the community include employees, suppliers, distributors, public sector partners, and the general public, while the term welfare can refer to health and safety, but also to psychological and emotional needs. In a community there is a sense of community expressed through a sense of co-operation, commitment to the well-being of the group, readiness for open communication and responsibility for itself and for members of the community. 
Community development relates to the initiatives that the community undertakes with the partnership with external organizations or corporations in order to empower individuals or groups of people (Maimunah, 2009, p.203). These initiatives are usually involve the training of the groups with the skills necessary to undertake the community change. Skills that need to be mastered are often concentrated on using local resources or strengthening political power by forming large social groups working on common goals. It is very important to define precisely the work with individuals and the ways of possible influence on the position of the community (considered in the context of larger social institutions). The basis of community development are education, training and empowerment of its members.

Social community development can also be viewed as a combination of processes, programs, strategies and activities that ensure community sustainability. The process of social community development itself is essentially a process of overcoming unwanted and unacceptable disparities between conditions and infrastructure, which negatively affects the quality of life in a place where a group of people lives and works (Garriga\&Mele, 2004). The development process works best in communities where all layers of society are linked in terms of social solidarity (Community Glossary, 2009).

The United Nations (1971) defines the development of the social community as an organized effort of individuals in the community to provide help in solving the problems it faces, with the minimal help of external organizations. This interpretations is also commonly used in practice, under which external organizations are understood to be governmental and non-governmental organizations, small and medium-sized enterprises, multinational corporation. Here the emphasis is on creativity and "self confidence" in the community when it comes to short-term and long-term goals, but the role of social responsibility of different types of companies is not defined (The United Nations, 1971). The process of developing active and sustainable communities, based on social justice and mutual respect, is also expressed. It is about the impact on structures of power to eliminate barriers that prevent people from participating in issues affecting their lives.

The engagement of local suppliers and the affinity for employment of local community members have proven to be a practice that is effective in creating a good reputation for the company. Large companies also contribute by supporting local entrepreneurial initiatives, that could be manifested through the establishment of mentoring programs for initiating business ventures for individuals or supporting certain entrepreneurial ventures of already existing small companies (Carroll\&Shabana, 2010). Generally, companies can provide a contribution to the local community in which they operate in many different ways: opening new jobs for the population, securing payments and benefits for employees, paying taxis. On the other hand, companies larger depends on the health of the population, their expertise and education, the business environment stability, the state of environment in a particular local community where they operate.

Social responsibility of companies implicates on community and its development in many ways. In principle, the role of corporate social responsibility in community development is the direct and indirect benefits received by the community from the companies and their social commitment to the community and its social system. The common roles of corporate social responsibility and community development are reflecting in the following (Maimunah, 2009, pp.204-206):

- $\quad$ sharing the negative consequences that result from industrialization, 
- creating closer and more coherent relations between the companies and the community, that becomes a social capital which is essential in community development,

- helping in talent detection among the employees and managers,

- the significant role in transfer of technology,

- helping in environment protection,

- achieving sustainable human rights protection,

- preserving interdependence and the close link between the community and the companies, which in long run creates sustainable development,

- $\quad$ applying the corporate social responsibility program as a help to alleviate poverty,

- $\quad$ achieving corporate sustainability goals.

The success of companies in the socially responsible business practices is determined by the factors of internal and external characters. Among the internal factors the most important are economic reasons, organizational culture, influence of business ethics, since the external factors include harmonization with legal requirements, technological influence, and national culture (Bichta, 2003).

Skills held by corporate social responsibility managers are among the internal factors that determine the success of social responsibility practices, in particular in helping the community. Since corporate social responsibility profession is a relatively new concept, skills and knowledge from other related specialization like human resources development, business ethics, community development, environmental management are of special value and importance (Career Service, 2009).

The specific skills that managers need to have in applying the concept of corporate social responsibility are difficult to distinguish, due to the different roles and range of disciplines involved. However, three groups of skills were identified: business skills, people skills, and technical skills (Maimunah, 2009, p.207). Business skills refer to ability to understand, communication skills, decision making and problem solving skills, leadership skills, information technologies, innovation skills. People skills include altruism, empathy, adaptability, integrity, political awareness. Technical skills primarily involve technical expertise, human rights, dialog with stakeholders, influence, sustainability.

Taking into account the mentioned groups of important skills, Maimunah (2009) emphasizes the six core competences that corporate social responsibility managers should need to possess: the ability to understand the community and its development, capacity building, business perception in the wider context, not only in terms of making profits, relationships with stakeholders, strategic approach to business and community partnership, and understanding of diversity. These managers have a wide range of work opportunities - in human resources, public relations, community resource development.

\section{The role of social investment in community driven development}

The fact is that in contemporary business conditions the new paradigm of social responsible business activities is getting more and more important. Consequently, in addition to being expected by companies to behave socially responsibly in their business, 
social investment programs that support community development come to expression. These programs are mainly realized in the communities where the indirect or negative influence of the company's business activities are reflected. Corporate social investments as a form of corporate social responsibility represent a comprehensive approach, or a corporate strategy focused on improving social, economic, and ecological well-being. It is especially important to differentiate the terms of corporate social responsibility and corporate social investment, since in practice they are sometimes identified. Corporate social investments actually represent the contribution of company (like employee volunteering, some kind of gift), where only those directly linked to core business activities realize benefits. On the other hand, corporate social responsibility is an initiative of company to take responsibility for environmental impact and social wellbeing (Naidoo, 2016).

The practice of corporate social investments has required to create certain rules or principles that will enable investors to be more effective and efficient in their investment activities. The principle for social responsible investments means a kind of international guidelines and statements that are relevant to the area of these investments. There have been a large number of rules created, presented and adopted at numerous conferences on social responsible issues, but the UN Principles for responsible investment, issued in 2006, has the greatest application (UN Principles, 2006). These principles were developed by an international group of institutional investors and were based on respecting the increasing relevance of environmental, social and corporate governance issues to investment practice. In the application of the principles it is strive to become the standard or norm of investment processes.

Several reasons have been identified for companies trying to invest resources for social, economic or environmental purposes (Campbell, 2007, pp. 950-952). Some companies are motivated by reputation, while in others primary motivational reasons are production, supply chain, marketing, distribution. Extractive companies, for instance, because of their great social impact on the community, have a strong incentive to invest in local community. Philanthropy, legal benefits, minimizing a negative impact and creating positive one, guaranteeing sustainable procurement bases, and creating new opportunities on the market can also represent an incentive for companies to invest. In many countries, every year is ranked a list that ranks socially responsible companies and, by itself, contributes to the positive promotion of the company in the community (David, Kline\&Dai, 2005). Also, for many employees, the wages and other benefits that they can realize are not enough, but when identifying the job, they also take into account that the company's business has been harmonized with their social values. Therefore, many companies will opt for social investments for attracting and recruiting talented professionals. In his paper, Irwin (2003) concludes that companies investing in the social investment program benefit from being able to differentiate themselves into highly competitive markets where consumers are becoming increasingly "sensitive" to the social role of the company. Thanks to the Internet, consumers can explore in more details the socially responsible practice of their favorite brand.

In order for corporate social investments to be sustainable, it is necessary to be treated as a business initiative (Owen, 2007). If they are viewed from the standpoint of the company business motives, even the most innovative, well-accepted social investment face failure over time. The program of corporate social investments has much 
greater chances for smooth functioning and survival if there is a correlation between this program and profitability and sustainability of the company (Pogutz, 2007). It is very important that there is a business plan with clear and measurable results.

As the most prominent potential outcomes of corporate social investments in community are the following:

- Improving reputation and better branding: Social community investment can allow access to new markets, reduce local regulatory barriers, provide opportunities for participation in local political processes, and enable the company to position itself in the market as more responsible and sustainable that its competitors.

- Social community investments as a strategic activity: Companies look at social community investments from a strategic perspective, which allows to create strategies that are aligned with business goals and to take advantage of core competencies.

- Combining philanthropic and commercial-community activities and community development: An increasing number of companies provide a wide range of business resources to support community development. Companies invest in order to increase local capacity and contribute to solving problems identified by the community. In some situation, companies cooperate with local NGOs.

- $\quad$ Creating partnerships: In order to meet a wide range of community needs it is necessary to create partnerships with non-profit organizations, government agencies, suppliers, other companies and their stakeholders.

- Creating a global focus: As generate more and more revenues and profits in realizing international activities, multinational companies redefine the "community", looking for communities in the regions where they factories work or trying to conclude contracts with companies managed by key suppliers.

- Measuring and reporting the benefits of corporate citizenship: Social community investments has traditionally been treated as a goodwill and has not been given special attention. However, companies today monitor and report on the impact of their social community investment on the business success and community satisfaction (Owen, 2007).

Social community investment in developing are especially pronounced and gain significance when communities become development partners, rather than passive recipients of philanthropic activities of companies. Among the factors most affecting the partnership between community and private sector stand out the recognition of the impact of globalization, the increased private capital flows in the developing countries, as well as the appreciation of potential private sector contribution. Thereby the private sector contribution does not only include financial support but can be considerably broadened, so it can include technical and managerial expertise, skills exchange, access to new markets and establishment of new business links (Owen, 2007, p.1). Two possible types of development partnerships between the private sector and the communities are emerging: Social Investment model, which involves financing programs with the main goal of improving the general well-being of the community, and the Economic Linkages model, that closely connect development initiatives and the private sector and includes 
training, direct employment, advancement of technical skills, microfinance, development of new supply bases and creation of links between the supply chains. The Economic Linkages model implies the integration of community engagement strategies in the key business activities of the companies and the development of consolidated markets in order to involve communities in the supply chain of companies. Consequently, this model enables the creation of sustainable and effective links between the community and the private sector (Owen, 2007, pp. 1-2).

As one of the models that enables the management of coherent and systematic partnerships between companies, government agencies, and local community organizations is the so-called tri-sector partnership model, based on agreement between companies, government and civil society (Warhurst, 2001, p. 59). The basic idea of the model is to determine the areas of concern by defining the partnership objectives as well as monitoring and reporting collaborative activities. Such a partnerships can be used as a mechanism for ensuring communication and participation in the decision-making process or as a form of financing social investment programs. In addition, the model helps to overcome the key challenges that industrial investment projects face, especially when it comes to:

- $\quad$ Social and political risk management

- Partner relationship management

- An effective assessment of the impact on the environment and the community

- Applying international standards and codes of good practice

- Consulting processes

- Integration of business strategies with regional and rural development plans and local education programs

- $\quad$ Building trust and cooperation

- Allocation of roles and responsibilities of partners and determining community expectations

- Orientation of social community investments to the local development priorities of the community

- $\quad$ Adequate managing foundations (Warhurst, 2001, pp 59).

Readiness to create effective partnerships means more credibility and trust in the relationship between the companies and the community. This is an important benefit for companies, increasing their chances for long-term community support.

\section{Conclusion}

In a situation where the market competition leaves no space for further growth and development of the company only on the basis of price and quality, the responsible behavior of company towards its employees, customers, suppliers, the wider community and the environment gets on its significance. Due to the high pressure of international institutions, governments, non-government organizations and customers, there is an increasing pressure on companies to apply the concept of socially responsible business and contributions to the society and the community in which they operate. That is why corporate social responsibility in recent years is increasingly becoming a very important 
factor in contemporary business world, that often requires companies to deal with the environment in which they operate, even to ensure resolving all problems that the community faces.

The organized public increasingly forces organizations to act more responsibly in relations with the local community and society as a whole, to behave more sustainably towards nature, and to more humane relationships with employees. The skills required by socially responsible managers vary depending on the different disciplines involved and in the face of accountable managers. The qualifications required by this field are not specified, but, having in mind that this is an area that is still developing, transferable skills and knowledge from related specialized areas such as environmental management, business ethics, human resources management or community development can be helpful.

On the other hand, the practice of socially responsible investing involves behavior and practices of the companies in relation to their social environment. It is possible to carry out a sort of advocacy by the owners to improve corporate social responsibility of their companies and investing in the community in order to support local development. The special type of social responsible investment is investing in the local community. Sometimes this is called alternative investments, because it reflects a different way of investing with a new vision. In our country, in current circumstances and environment, this way of responsible investing has been part of the practice of large enterprises, that have influenced the development of cities and regions. In the world, this type of investing has usually done by the provision of funds to local funds through which give loans to local businesses, cooperatives or companies that are oriented towards the community. This kind of alternative investors want to help in the creation of new jobs, providing basic services or positions of employees and consumers. This method of investing is an effective way for raise capital for local entrepreneurship development. A very important factor for this kind of investment funds in the community are volunteers and funding from public sources, which make it possible to establish funds and identify those who need to borrow funds in order to manage risk and raised capital.

Depending on the extent to which the company is deliberately engaged in socially responsible projects it manages, as well as the principles of their realization, there are certain methods of achieved results affirmation. For companies it is not enough to develop and implement socially responsible principles and initiatives, but it is also important to effectively promote them, with adequate internal and external communication.

\section{References}

Barnett, M. (2007). Stakeholder influence capacity and the variability of financial returns to corporate social responsibility. Academy of Management Review, 32(3), 794-816.

Bichta, C. (2003). Corporate socially responsible industry (CSR) practices in the context of Greek. Social Responsibility and Environmental Management, 10, $12-24$. 
Branco Castelo, M. \& Rodrigues Lima, L. (2007). Positioning Stakeholder Theory within the Debate on Corporate Social Responsibility. Electronic Journal of Business Ethics and Organization Studies, 12(1), 5-15.

Campbell, L. J. (2007). Why Would Corporation Behave in Socially Responsible Ways? An Institutional Theory of Corporate Social Responsibility. Academy of Management Review, 32 (3), 946-967.

Career Service (2009). Corporate Social Responsibility and Ethical Careers. Available at: http://www.careers.ed.ac.uk

Carroll, B.A.\&Shabana, M.K. (2010). The Business Case for Corporate Social Responsibility: A Review of Concepts, Research and Practice. International Journal of Management Reviews, 12(1), 85-105.

Community Glossary (2009), avaliable at: http://www.findmehere.com/search/ dictionary/c_index.htm\#com,

Crane A.\&Matten D. (2007). Business Ethics: Managing Corporate Citizenship and Sustainability in the Age of Globalization. Oxford University Press

David, P, Kline, S.\&Dai, Y. (2005). Corporate Social Responsibility Practices, Corporate Identity, and Purchase Intention: A Dual-process Model, Journal of Public Relation Research, 17 (3), 291-313.

Garriga, E.\&Mele,D. (2004). Corporate Social Responsibility Theories: Mapping the Territory, 53, 51-71.

Irwin, R. (2003). Corporate social investment and branding in the new South Africa. Journal of Brand Management, 10(4), 303-311.

Kotler, P. \& Lee, N. (2005). Corporate Social Responsibility. New Jersey: John Wiley \& Sons, Inc.

Kourula, A. \& Halme M. (2008). Corporate Responsibility Type and Engagement with Nongovernmental Organizations: An Exploration of Business and Societal Outcomes. Corporate Governance, 8(4), 557-570.

Maimunah, I. (2009). Corporate social responsibility and its role in community development: an international perspective. The Journal of International Social Research, 2(9), 199-209.

Moir, L. (2001) What Do We Mean by Corporate Social Responsibility? Corporate Governance, 1 (2), pp. 16-22.

Naidoo, N. (2016). How Corporate Social Investment Can Improve Your PR Game, preuzeto sa: http://peakco.com/how-corporate-social-investment-can-improveyour-pr-game/ [22.8.2018.]

Nga, J.L.H. (2015). Global Financial Crisis and Philanthropy: Malaysian Case. Cosmopolitan Civil Societies Journal, 7(2), 19-31.

Owen, P. D. (2007) Beyond Corporate Social Responsibility: The Scope for Corporate Investment in Community Driven Development. World Bank Report No. 37379GLB

Pogutz, S. (2007) Sustainable Development, Corporate Sustainability, and Corporate Social Responsibility: The Need for an Integrative Framework, International 
Conference of the Greening of Industry Network, Canada, Waterloo, Ontario: Wilfrid Laurier University, June: 15-17

Post J, Lawrence A, Weber J. (2002). Business and Society, Corporate Strategy, Public Policy, Ethics. Boston: McGraw-Hill Irving

Tsoutsoura, M. (2004). Corporate Social Responsibility and Financial Performance(UC Berkeley Working Paper Series), California, Berkeley: Institute for Research on Labor and Employment

United Nations (1971). Popular Participation in Development: Emerging Trends in Community Development. New York: UN Department of Economic Affairs

The UN Principles for responsible investment and the OECD guidelines for multinational enterprises: complementarities and distinctive contributions (2006), Working document prepared by the OECD Secretariat with the Secretariat of the UNEP Finance Initiative

Zadek, S. (2007), The Civil Corporation: The New Economy of Corporate Citizenship. London: Earthscan Publications Ltd.

Warhurst, A. (2001), Corporate Citizenship and Corporate Social Investment. Drivers of Tri-Sector Partnerships. Journal of Corporate Citizenship, 1, 57-73. 